AgnieSZKa ŚWIĘTEK

Uniwersytet Pedagogiczny w Krakowie, Polska - Pedagogical University of Cracow, Poland

\title{
Miejsce podstaw przedsiębiorczości w zreformowanej polskiej szkole ponadpodstawowej i ich korelacje z innymi przedmiotami szkolnymi
}

\section{Position of the Basics Basics of Entrepreneurship in Reformed Secondary School in Poland and its Correlation with Other Subjects}

Streszczenie: Wprowadzana obecnie do polskich szkół reforma oświaty spowoduje znaczne zmiany organizacyjne i merytoryczne w kształceniu polskich uczniów, $\mathrm{w}$ tym $\mathrm{w}$ zakresie podstaw przedsiębiorczości. Przedmiotem artykułu jest miejsce przedmiotu podstawy przedsiębiorczości w zreformowanej szkole średniej. W pracy autorka realizuje następujące cele badawcze: ustalenie pozycji przedmiotu podstawy przedsiębiorczości wśród innych przedmiotów szkolnych, wskazanie przedmiotów szkolnych, których źródła naukowe i założenia dydaktyczne są koherentne z założeniami podstaw przedsiębiorczości, analiza i wskazanie treści podstaw programowych: podstaw przedsiębiorczości, geografii i wiedzy o społeczeństwie, które umożliwiają przeprowadzenie korelacji, oraz analiza możliwości realizacji korelacji lub integracji międzyprzedmiotowej wskazanych przedmiotów wg monodyscyplinarnego, interdyscyplinarnego i multidyscyplinarnego modelu kształcenia. Wyniki analizy pozycji przedmiotu podstawy przedsiębiorczości wykazały, że z punktu widzenia ramowego planu nauczania przedmiot nie zyska na znaczeniu. Zakres treści kształcenia podstaw przedsiębiorczości sytuuje go jednak jako znaczący przedmiot dla rozwoju ekonomicznego ucznia. Przedmiotami, których źródła naukowe i założenia dydaktyczne w wielu zakresach są zbliżone do podstaw przedsiębiorczości, są geografia i wiedza o społeczeństwie. W artykule wskazano liczne treści kształcenia wskazanych przedmiotów, które umożliwiają przeprowadzenie korelacji. Modelem kształcenia najbardziej sprzyjającym budowaniu u ucznia holistycznej wiedzy ekonomicznej jest model multidyscyplinarny.

Abstract: The educational reform which is being introduced into Polish schools is going to cause significant organisational and technical changes in educating Polish students, also in the field of Basics of Entrepreneurship. The paper analyses the position occupied by the Basics of Entrepreneurship in secondary school after the reform. In her paper, the author achieves the following research goals: she defines the position occupied by the Basics of Entrepreneurship vis-a-vis other school subjects, identifies the subjects whose scientific sources and didactic foundations are consistent with the assumptions underlying the introduction to business, analyses and identifies the content of the curriculum for: the Basics of Entrepreneurship, Geography and Civics which allow for such a correlation, and analyses a potential inter-subject correlation of integration of some subjects in line with a mono-disciplinary, interdisciplinary 
and multidisciplinary educational model. According to the analysis of the Basics of Entrepreneurship, the subject will not grow in importance from the point of view of the curriculum framework. However, the scope of the educational content of the Basics of Entrepreneurship places it as a subject important for economic development of a student. Subjects having their scientific sources and didactic assumptions similar in many aspects to the Basics of Entrepreneurship are geography and civics. The article identifies the sample educational content of the subjects that allow for the above-described correlation. The multidisciplinary model is the educational model offering the strongest support of holistic economic knowledge in students.

Słowa kluczowe: korelacja międzyprzedmiotowa; podstawa programowa; podstawy przedsiębiorczości; reforma systemu oświaty

Key words: core curriculum; cross-subject correlation; Basics of Entrepreneurship; reform of the education system

Otrzymano: 12 listopada 2018

Received: 12 November 2018

Zaakceptowano: 28 lutego 2019

Accepted: 28 February 2019

\section{Sugerowana cytacja/Suggested citation:}

Świętek A. (2019). Miejsce podstaw przedsiębiorczości w zreformowanej polskiej szkole ponadpodstawowej i ich korelacje z innymi przedmiotami szkolnymi. Przedsiębiorczość - Edukacja [Entrepreneurship - Education], 15(1), 34-46. doi: 10.24917/20833296.151.3

\section{Wstęp}

„Współczesne wyzwania cywilizacyjne stawiają nowe, wysokie zadania w zakresie edukacji i przygotowania do pełnienia określonych ról zawodowych. Zadania są bowiem determinowane rozwojem społecznym, gospodarczym i kulturalnym, stanem świadomości społecznej oraz potrzebami i zainteresowaniami ludzi żyjących w określonych strukturach społeczno-ekonomicznych. One wyznaczają zasadnicze priorytety polityki oświatowej oraz konstrukcję systemu edukacji” (Zioło, 1999: 127). Ważną rolę w konstrukcji owego systemu kształcenia uczniów powinna odgrywać edukacja na rzecz przedsiębiorczości jako edukacja umożliwiająca nauczycielom przygotowanie uczniów do ważnego aspektu ich dorosłego życia (Rachwał, 2005; Wach, 2013). Czy takie będzie jej znaczenie w zreformowanej polskiej szkole?

Wdrażana obecnie w polskim systemie oświaty reforma szkolnictwa podstawowego i ponadpodstawowego spowoduje zmiany w zakresie występujących dotychczas przedmiotów szkolnych, ich wymiaru godzinowego, a także w treściach kształcenia, które będą w ich ramach realizowane. Nowym wymogiem (dotyczącym zarówno treści, jak i działań dydaktycznych), pojawiającym się w nowej podstawie programowej do szkoły ponadpodstawowej jest stosowanie korelacji. W części podstawy programowej dotyczącej podstaw przedsiębiorczości korelację uznano za jeden z ważnych warunków i sposobów realizacji kształcenia tego przedmiotu, podając inne przedmioty, z których treściami powinna ona następować, i najważniejsze zagadnienia sugerowane do scalania. Dokument nie precyzuje jednak, jaki rodzaj korelacji należy stosować w praktyce szkolnej oraz jaki model kształcenia ma być w tym celu przez nauczycieli wykorzystywany (Rozporządzenie Ministra Edukacji Narodowej z dnia 14 lutego 2017 r. w sprawie podstawy programowej 
wychowania przedszkolnego oraz podstawy programowej kształcenia ogólnego dla szkoły podstawowej, w tym dla uczniów $z$ niepetnosprawnościa intelektualna $w$ stopniu umiarkowanym lub znacznym, kształcenia ogólnego dla branżowej szkoły I stopnia, kształcenia ogólnego dla szkoły specjalnej przysposabiającej do pracy oraz kształcenia ogólnego dla szkoły policealnej, Dz.U. 2017, poz. 356).

Ze względu na ważne zmiany w kształceniu podstaw przedsiębiorczości w Polsce wywołane reformą szkolnictwa autorka postanowiła uczynić przedmiotem niniejszego artykułu miejsce przedmiotu podstawy przedsiębiorczości w zreformowanej szkole średniej i wskazać możliwe korelacje tego przedmiotu z innymi przedmiotami szkolnymi. Autorka chce zweryfikować hipotezę, że pomimo zmian programowych podstawy przedsiębiorczości w szkole ponadpodstawowej nadal będą miały niższą pozycję od większości przedmiotów szkolnych. Celem pracy jest ustalenie, jakie miejsce zajmują podstawy przedsiębiorczości w kształceniu młodych ludzi. Celami szczegółowymi pracy są:

- ustalenie pozycji przedmiotu podstawy przedsiębiorczości na tle innych przedmiotów szkolnych,

- wskazanie przedmiotów szkolnych, których źródła naukowe i założenia dydaktyczne są podobne do założeń podstaw przedsiębiorczości,

- analiza i wskazanie treści podstaw programowych: podstaw przedsiębiorczości, geografii i wiedzy o społeczeństwie, które umożliwiają przeprowadzenie korelacji,

- analiza możliwości korelacji lub integracji międzyprzedmiotowej wskazanych przedmiotów wg monodyscyplinarnego, interdyscyplinarnego i multidyscyplinarnego modelu kształcenia.

Dla osiągnięcia postawionych celów autorka wykorzystywała analizę (funkcyjną i porównawczą) dwóch aktów prawa oświatowego: ramowego planu nauczania (Ramowy plan nauczania...) oraz nowej podstawy programowej kształcenia ogólnego (Rozporządzenie...), skupiając się w szczególności na treściach kształcenia podstaw przedsiębiorczości, geografii i wiedzy o społeczeństwie.

\section{Miejsce podstaw przedsiębiorczości w zreformowanej szkole - ujęcie formalne i koncepcyjne}

Znaczenie przedmiotu nauczania w szkole w powszechnie przyjętym rozumieniu określa jego formalna pozycja, mierzona m.in. liczbą godzin przewidzianych na jego realizację, etapem edukacyjnym i poziomem, na którym występuje.

Przedmiot podstawy przedsiębiorczości po reformie oświaty nadal będzie występował w szkole ponadpodstawowej jako przedmiot obowiązkowy, lecz będzie realizowany wyłącznie w zakresie podstawowym. Na jego realizację przewidziano łącznie dwie godziny w całym cyklu kształcenia w szkole średniej - po jednej godzinie lekcyjnej tygodniowo w klasie II i III (Ramowy plan nauczania...). Liczba godzin przeznaczonych na nauczanie podstaw przedsiębiorczości jest zatem niewielka. Równie małą liczbę godzin ma jedynie wiedza o społeczeństwie, a mniejszą przeznaczono tylko na edukację dla bezpieczeństwa i występujące wariantowo: filozofię, plastykę i muzykę (rycina 1).

Zakres treści realizowanych na podstawach przedsiębiorczości jest natomiast bardzo szeroki: „Przedmiot podstawy przedsiębiorczości stanowi [...] syntezę wybranych celowo elementów wiedzy z zakresu ekonomii, zarządzania i finansów, wzbogaconej elementami geografii społeczno-ekonomicznej, politologii, socjologii, psychologii oraz prawa.” 
Rycina 1. Tygodniowy obowiązkowy wymiar godzin przedmiotów szkolnych w klasach I-IV szkoły ponadpodstawowej

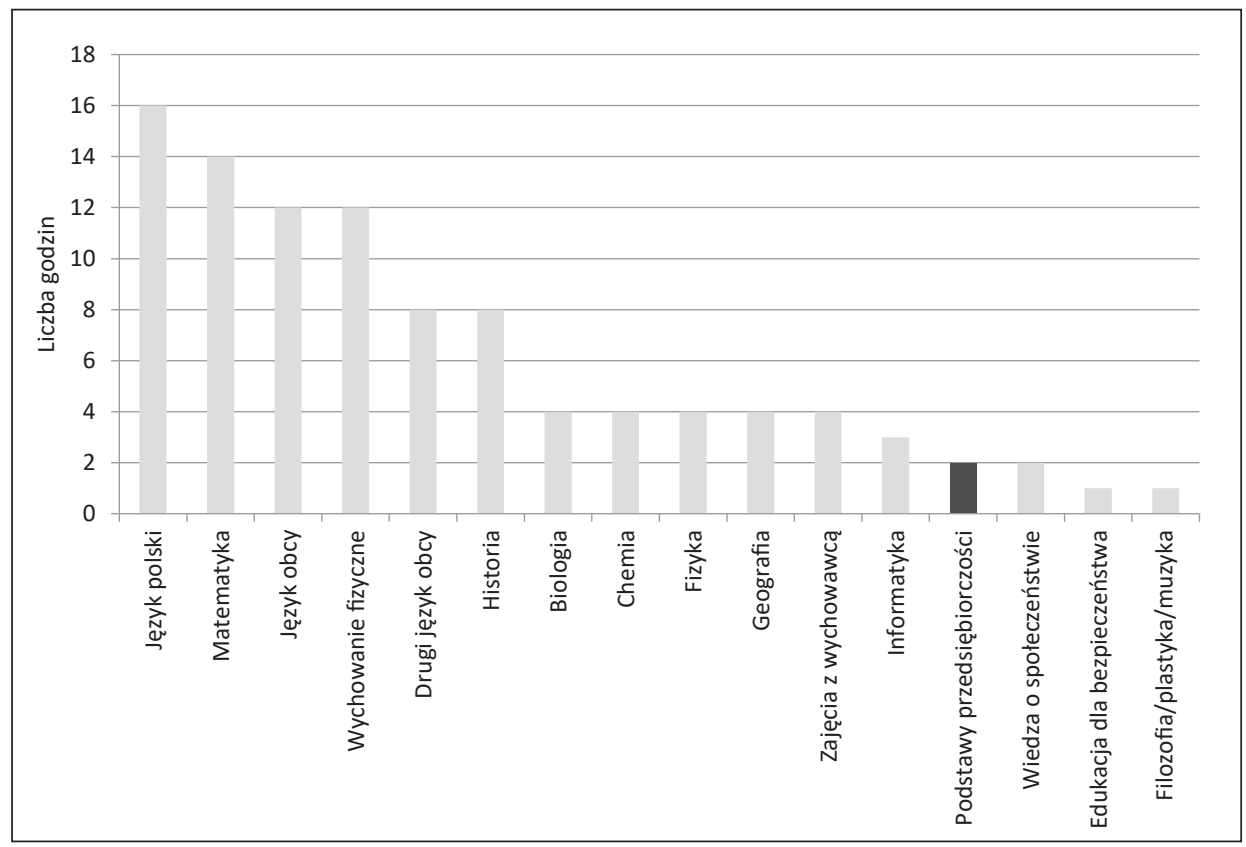

Źródło: opracowanie własne na podstawie: Ramowy plan nauczania...

(Rozporządzenie...). Tematyka podstaw przedsiębiorczości obejmuje takie zagadnienia, jak: gospodarka rynkowa, rynek finansowy, rynek pracy i przedsiębiorstwo.

Przedmiot podstawy przedsiębiorczości po reformie, tak jak do tej pory, nie będzie przedmiotem maturalnym. $Z$ jednej strony obniża to zdaniem nauczycieli jego range w oczach ucznia, z drugiej jednak sprawia, że w trakcie jego realizacji nauczyciele mogą Z większą swobodą skupić się nie tylko na osiąganiu celów kształcenia w zakresie wiedzy, rozumienia i kształtowania umiejętności przedmiotowych (czemu poświęca się niemal cały czas na lekcjach przedmiotów maturalnych), lecz również na osiągnięciu ważnych i bardzo trudno mierzalnych celów formalnych w zakresie kształtowania przez uczniów kompetencji oraz celów wychowawczych w postaci wypracowania postaw. Przedsiębiorczość, będąc praktyką (nie nauką), na owych praktycznych umiejętnościach i rozwoju kompetencji przedsiębiorczych powinna się skupiać. Niestety, jak pokazują wyniki badań, młodzi ludzie, którzy w ogromnej większości uczęszczali na podstawy przedsiębiorczości w szkole, mają trudności kompetencyjne na rynku pracy i niejednokrotnie nisko oceniają realizację przedmiotu w ich szkole (Świętek, 2012).

Z formalnego punktu widzenia, zgodnie z zapisami Ramowego planu nauczania i nowej podstawy programowej (Rozporządzenie...) pozycja podstaw przedsiębiorczości po reformie edukacji nie zmieni się znacząco i nadal pozostanie niezbyt wysoka. Analizując tytułowe „miejsce” podstaw przedsiębiorczości w zreformowanej szkole, oprócz formalnej pozycji przedmiotu, należy jednak również wziąć pod uwagę jego znaczenie merytoryczne i rolę, którą odgrywa w przygotowaniu młodego człowieka do dorosłego życia, na tle innych przedmiotów. 
Analiza zakresu treści kształcenia zawartych w nowej podstawie programowej do zreformowanej szkoły ponadpodstawowej wykazuje, że wykształcenie ogólne, które uzyska uczeń, obejmuje wybraną wiedzę i umiejętności z:

- nauk humanistycznych (zdobywane na języku polskim i językach obcych, historii i filozofii),

- nauk ścisłych i przyrodniczych (na biologii, chemii, fizyce, geografii - w jej części dotyczącej geografii fizycznej, matematyce i informatyce),

- nauk społecznych (na podstawach przedsiębiorczości, wiedzy o społeczeństwie, geografii - w jej części dotyczącej geografii społeczno-ekonomicznej, edukacji dla bezpieczeństwa i wychowania do życia w rodzinie,

- nauk teologicznych (na etyce),

- oraz ze sztuki (na muzyce, plastyce, historii muzyki i historii sztuki).

Kształcenie szkolne nie obejmuje realizacji treści z takich obszarów, jak nauki inżynieryjno-techniczne, nauki medyczne i nauki o zdrowiu oraz nauki rolnicze. Określenie „miejsca” danego przedmiotu nie powinno sprowadzać się do jego zaszeregowania wg liczby godzin, lecz wymaga wskazania jego pozycji wśród innych składowych procesu kształcenia. Znaczenie przedmiotu w konstrukcji całego systemu kształcenia należy mierzyć głównie jego wkładem w przygotowanie młodego człowieka do dorosłego życia. W badaniach geograficznych uwzględnia się dwie kategorie badawcze pozwalające na ocenę życia człowieka. Są to: poziom życia (w którym bada się warunki życia ludności za pomocą obiektywnych wskaźników, np. wielkości dochodu czy metrażu mieszkania) i jakość życia (odnoszącą się do subiektywnej oceny własnej egzystencji przez badanych - ich zadowolenia ze swojego poziomu życia). Ocena poziomu życia opiera się na analizie potrzeb człowieka i stopniu ich zaspokojenia. Najczęstszymi potrzebami, które obiektywnie określają warunki życia ludzi, są: sytuacja na rynku pracy, sytuacja finansowa, sytuacja mieszkaniowa i poziom wyposażenia w infrastrukturę gospodarstw domowych oraz dostęp do wybranych usług (np. edukacji, publicznej służby zdrowia czy dóbr kultury) (Świętek, 2016).

Podstawy przedsiębiorczości jako najważniejszy przedmiot przygotowujący młodych ludzi do ekonomicznego aspektu ich życia, a więc głównego faktora poziomu życia człowieka, zdecydowanie zyskuje $z$ tej perspektywy na znaczeniu. W zreformowanej szkole średniej prócz podstaw przedsiębiorczości cel ten realizowany będzie częściowo również na dwóch innych przedmiotach wywodzących się z obszaru nauk społecznych: wiedzy o społeczeństwie i geografii.

W myśl koncepcji holistycznego budowania wiedzy ucznia kształcenie ekonomiczne młodego człowieka winno odbywać się w procesie scalania treści ekonomicznych z różnych przedmiotów szkolnych, na których są one poruszane. Umowne podziały przedmiotowe nie powinny dezintegrować kompleksowej wiedzy i umiejętności. Scalanie jest najbardziej zasadne przy spójności dziedzin naukowych, z których dane przedmioty się wywodzą, i tożsamych założeń dydaktycznych i wychowawczych.

Wspólnymi źródłami naukowymi podstaw przedsiębiorczości, wiedzy o społeczeństwie i geografii (społeczno-ekonomicznej) są nauki społeczne, a wśród nich głównie: geografia społeczno-ekonomiczna i gospodarka przestrzenna, ekonomia i socjologia (tabela 1). Powoduje to, że przedmioty te mogą być nauczane blokowo w zakresie wybranych treści, i umożliwia wykorzystanie wspólnych prostych metod badań naukowych ich dyscyplin źródłowych jako metod kształcenia. 
Miejsce podstaw przedsiębiorczości w zreformowanej polskiej szkole ponadpodstawowej...

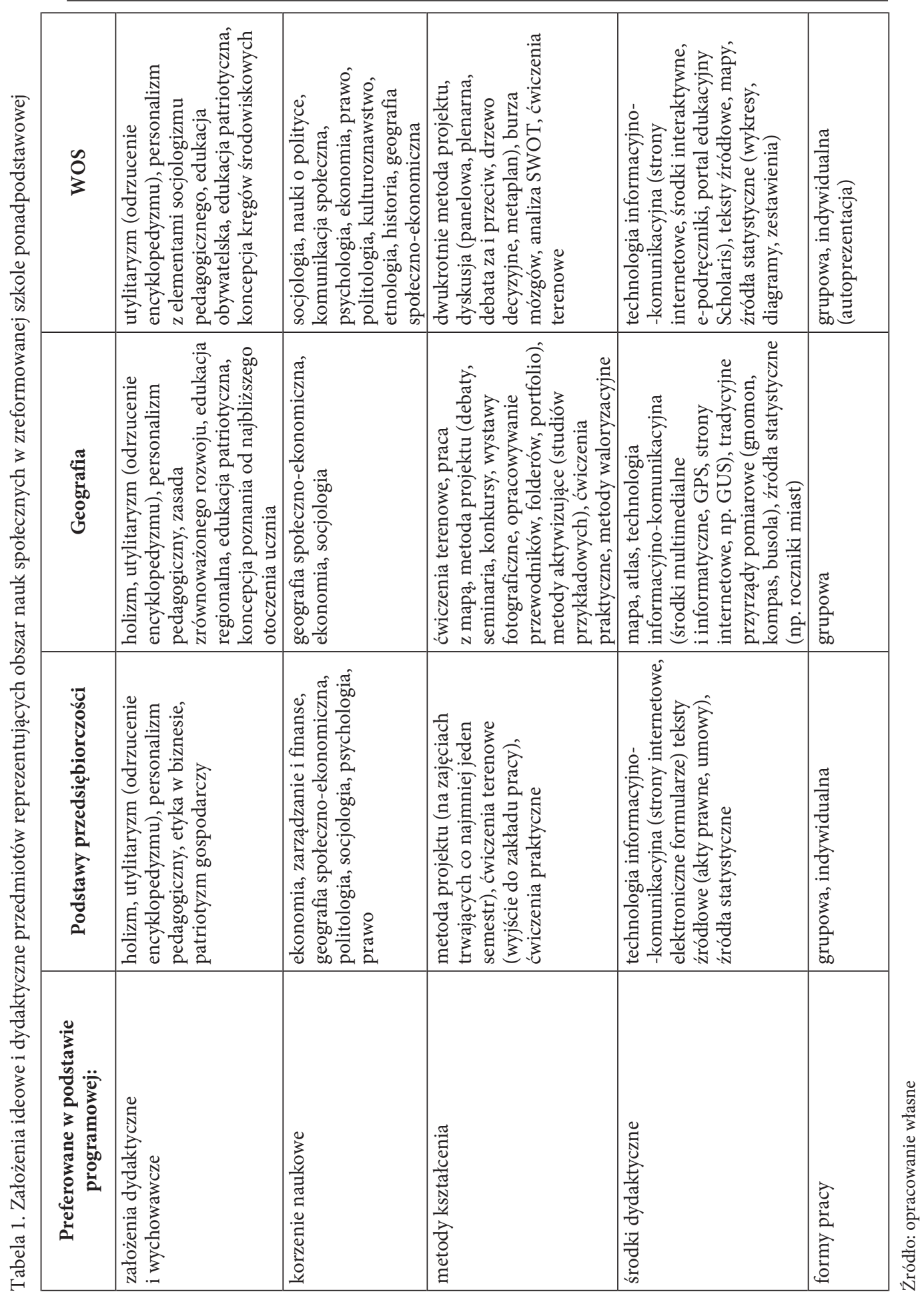


Wskazane przedmioty mają również tożsame ideowo założenia dydaktyczne i wychowawcze (tabela 1). Twórcy podstaw programowych wszystkich trzech przedmiotów zakładają ich utylitaryzm (praktyczność zdobywanej na nich wiedzy) i silnie odchodzą od schematycznego przedstawiania i pamięciowego przyswajania wiedzy. O skupieniu uwagi na zdobywaniu umiejętności świadczy konstrukcja celów kształcenia zawartych w podstawach programowych wszystkich trzech przedmiotów. Zakłada się w nich, że uczeń będzie samodzielnie szukał i analizował informacje, by następnie skonstruować z nich użyteczną wiedzę. Wszystkie trzy przedmioty zakładają centralą pozycję ucznia w procesie kształcenia i konieczność skupienia uwagi nauczyciela na jego potrzebach i rozwoju. Na wiedzy o społeczeństwie ów personalizm pedagogiczny rozpatrywany jest dodatkowo przez pryzmat funkcjonowania jednostki w grupie, przyjmując formę socjologizmu pedagogicznego, w myśl którego jednostka jest indywiduum stanowiącym element różnych grup społecznych. Na wszystkich trzech przedmiotach występują cele kształcenia związane z edukacją patriotyczną, przy czym na podstawach przedsiębiorczości uwaga skupia się na patriotyzmie gospodarczym, a na wiedzy o społeczeństwie wyraża się w formie edukacji obywatelskiej.

Tożsame źródła i założenia dydaktyczne podstaw przedsiębiorczości, geografii i wiedzy o społeczeństwie przekładają się również na praktykę szkolną w zakresie konieczności stosowania zbliżonych metod kształcenia, środków dydaktycznych i form pracy (tabela 1). W podstawach programowych wszystkich wskazanych przedmiotów sugeruje się stosowanie metody projektu i ćwiczeń terenowych. Wśród środków dydaktycznych wyróżnia się technologie informacyjno-komunikacyjną oraz dane statystyczne, a najbardziej preferowaną formą pracy jest praca grupowa.

Dokonana analiza miejsca podstaw przedsiębiorczości w kształceniu uczniów wykazała, że jest ono różne w zależności od przyjętego kryterium rozpatrywania. Z formalnego punktu widzenia liczba godzin przewidziana na realizację przedmiotu, występowanie wyłącznie w zakresie podstawowym i jego „niematuralność” składają się na jego niską pozycję. Z punktu widzenia całościowej koncepcji kształcenia ucznia w szkole ponadpodstawowej, rozumianego jako przygotowanie do dorosłego życia, zakres treści przedmiotu podstawy przedsiębiorczości sprawia, że jest on przedmiotem ważnym, wchodzącym wraz z geografią i wiedzą o społeczeństwie w skład dużego bloku tematycznego reprezentującego w szkole obszar nauk społecznych.

\section{Budowanie spójnego obrazu świata - holizm w praktyce szkolnej}

Holizm to pogląd rozpatrywany na gruncie nauk społecznych jako zaprzeczenie indywidualizmu metodologicznego, według którego zjawiska społeczne tworzą układy całościowe (Stepulak, 2017). Znalazł on swoje istotne zastosowanie w nowo powstających dyscyplinach nauk społecznych, w szczególności w pedagogice holistycznej. Zgodnie z jej założeniami, w holistycznym wychowaniu i nauczaniu nie chodzi wyłącznie o skuteczniejszą transmisję wiedzy, lecz o przekazywanie uczniom spójnej wizji świata (Szyszko-Bohusz, 2002). Wspólne korzenie naukowe i zbliżone założenia dydaktyczne i wychowawcze podstaw przedsiębiorczości, geografii i wiedzy o społeczeństwie sprawiają, że są to przedmioty predysponowane do realizowania idei holizmu w praktyce szkolnej przez stosowanie korelacji. 
Korelacja to łączenie treści różnych przedmiotów nauczania w celu ich merytorycznej integracji (Okoń, 2003). „Tradycyjne rozumienie korelacji w nauczaniu sprowadza się do synchronizacji w nauczaniu zbliżonych do siebie treści różnych przedmiotów [...]. Bardziej współczesne rozumienie korelacji polega na merytorycznym wiązaniu ze sobą treści z różnych przedmiotów nauczania i tworzeniu układów integrujących [...]" (Grządziel i in., 2011: 3-4). W literaturze dydaktycznej spotyka się trzy szczegółowe pojęcia związane $z$ korelacją. Są to: korelacja przedmiotowa (zakładająca scalanie treściowe na jednym przedmiocie szkolnym), korelacja międzyprzedmiotowa (zakładająca scalanie treściowe na co najmniej dwóch przedmiotach) i integracja międzyprzedmiotowa (polegającą na łączeniu zarówno treści, jak i działań dydaktycznych co najmniej dwóch przedmiotów szkolnych). „Integracji w procesie kształcenia nie osiąga się jednak przez mechaniczne scalanie, lecz w realizowanym przez nauczyciela procesie dydaktycznym [...]” (Zawiślak, 2000: 88). Proces dydaktyczny z kolei to „uporządkowany w czasie ciąg zdarzeń obejmujący takie czynności nauczycieli i uczniów, ukierunkowane przez odpowiedni dobór celów i treści oraz takie warunki i środki, jakie służą wywoływaniu zmian w uczniach, stosownie do przyjętych celów kształcenia" (Okoń, 2003: 133).

W praktyce szkolnej stosowane są trzy modele kształcenia uwzględniające korelację lub integrację międzyprzedmiotową: model jednoprzedmiotowy (monodyscyplinarny), wieloprzedmiotowy (multidyscyplinarny) i międzyprzedmiotowy (interdyscyplinarny) (rycina 2).

Model jednoprzedmiotowy (monodyscyplinarny) polega na stosowaniu korelacji przez nauczyciela w ramach własnego przedmiotu szkolnego przez wplatanie przez niego w tok własnych lekcji wiedzy i umiejętności z innych przedmiotów. Realizacja korelacji podstaw przedsiębiorczości, geografii i wiedzy o społeczeństwie z wykorzystaniem tego modelu opierałaby się więc na wzajemnym wzbogacaniu przez nauczycieli treści swoich przedmiotów odwołaniami do treści pozostałych dwóch przedmiotów. Taki rodzaj scalania nie wymaga od nauczycieli współpracy i synchronizacji działań w czasie, a jedynie dobrej znajomości rodzaju i rozkładu treści kształcenia wszystkich trzech przedmiotów szkolnych. W nowej podstawie programowej do szkoły ponadpodstawowej do geografii

Rycina 2. Modele kształcenia umożliwiające korelację w praktyce szkolnej

\begin{tabular}{|c|c|c|}
\hline $\begin{array}{l}\text { - integrowanie wiedzy z innych } \\
\text { dziedzin na swoim przedmiocie } \\
\text { - wzbogacanie własnego przedmiotu } \\
\text { o treści innych przedmiotów }\end{array}$ & $\begin{array}{l}\text { - budowanie obrazu całości danego } \\
\text { problemu edukacyjnego przez } \\
\text { ogląd z różnych punktów widzenia } \\
\text { (holizm) } \\
\text { - współpraca nauczycieli } \\
\text { w zespole międzyprzedmiotowym } \\
\text { - dzielenie treści szczegółowych } \\
\text { (składowych problemu) pomiędzy } \\
\text { przedmioty } \\
\text { - brak konieczności synchronizacji } \\
\text { nauczania w czasie }\end{array}$ & $\begin{array}{l}\text { - budowanie obrazu całości danego } \\
\text { problemu edukacyjnego przez } \\
\text { ogląd z różnych punktów widzenia } \\
\text { (holizm) } \\
\text { - współpraca nauczycieli nad } \\
\text { tworzeniem wspólnej formy } \\
\text { realizacji treści (ustalenia rodzaju } \\
\text { scalania, np. treściowego } \\
\text { i metodologicznego) } \\
\text { - wymaga synchronizacji } \\
\text { w czasie }\end{array}$ \\
\hline $\begin{array}{l}\text { Model } \\
\text { jednoprzedmiotowy } \\
\text { (monodyscyplinarny) }\end{array}$ & $\begin{array}{l}\text { Model } \\
\text { wieloprzedmiotowy } \\
\text { (multidyscyplinarny) }\end{array}$ & $\begin{array}{l}\text { Model } \\
\text { międzyprzedmiotowy } \\
\text { (interdyscyplinarny) }\end{array}$ \\
\hline
\end{tabular}

Źródło: opracowanie własne 
i wiedzy o społeczeństwie znalazły się liczne treści możliwe do skorelowania z podstawami przedsiębiorczości.

W podstawie programowej do geografii są to zagadnienia dotyczące:

- struktury zatrudnienia, rynku pracy, bezrobocia,

- gospodarki opartej na wiedzy i społeczeństwa informacyjnego,

- mierników i wskaźników rozwoju społeczno-gospodarczego (PKB, HDI),

- inwestycji krajowych i zagranicznych w rozwoju gospodarczym,

- procesów integracji gospodarczej na świecie,

- integracji europejskiej,

- globalizacji i roli korporacji w gospodarce,

- deindustrializacji i reindustrializacji,

- przemysłu zaawansowanych technologii,

- przemian strukturalnych przemysłu Polski,

- korzystania z różnych źródeł informacji (wykresów, map, danych statystycznych).

Z podstawy programowej do wiedzy o społeczeństwie można natomiast wykorzystywać na podstawach przedsiębiorczości treści związane z:

- komunikacją interpersonalną,

- budżetami gospodarstwa domowego i jednostek samorządu terytorialnego,

- systemem ubezpieczeń społecznych i zdrowotnych,

- metodami ograniczania bezrobocia,

- Unią Europejską.

Drugi model kształcenia możliwy do wykorzystania to model wieloprzedmiotowy (multidyscyplinarny). Polega on na współpracy nauczycieli różnych przedmiotów w zespole, w którym wspólnie dokonują analizy zapisów podstaw programowych w celu selekcji koherentnych treści kształcenia. Po ich wskazaniu wspólnie decydują, przy pomocy jakich metod i środków dydaktycznych oraz w jakim dokładnie zakresie treści te będą przez nich realizowane na poszczególnych przedmiotach. Dzięki takiej współpracy nauczycieli uczniowie mogą poznać dane zagadnienie z punktu widzenia różnych nauk, przez co możliwe jest zbudowanie w ich umysłach holistycznego obrazu rozpatrywanego problemu. Przykładem zagadnienia możliwego do wykorzystania, a pojawiającego się na wszystkich trzech analizowanych przedmiotach szkolnych, jest rynek pracy (tabela 2). Na lekcjach podstaw przedsiębiorczości uczeń poznaje ekonomiczne reguły rządzące rynkiem pracy (popytem i podażą na pracę), poznaje formy zatrudnienia, wybrane przepisy związane z zatrudnieniem, uczy się, jak planować własną karierę zawodową i ubiegać się o pracę. Na wiedzy o społeczeństwie wiedzę tę może uzupełnić, poznając rodzaje umów i system ubezpieczeń społecznych. Na geografii natomiast skonfrontuje posiadane kwalifikacje i plany zawodowe $\mathrm{z}$ warunkami na rynku pracy przez analizowanie przyczyn i struktury bezrobotnych na lokalnym rynku pracy.

Ostatnim analizowanym modelem pozwalającym osiągnąć największą efektywność w korelacji jest model międzyprzedmiotowy (interdyscyplinarny). Zakłada on pełną współpracę nauczycieli różnych przedmiotów szkolnych na rzecz wspólnej realizacji treści kształcenia. Różnica polega jednak na tym, że w tym modelu nauczyciele planują wspólną realizację wybranych, kompatybilnych celów kształcenia swoich przedmiotów. Praca nauczycieli wymaga więc pełnej synchronizacji. Dzięki tworzeniu wspólnych przedsięwzięć nauczyciele mogą osiągać z uczniami dodatkowe cele dydaktyczne i wychowawcze, wykraczające poza te cele, które wynikają z zapisów podstaw programowych ich przedmiotów, 
Tabela 2. Treści kształcenia dotyczące rynku pracy zawarte w nowej podstawie programowej do szkoły ponadpodstawowej przedmiotów: podstawy przedsiębiorczości, geografia i wiedza o społeczeństwie

\begin{tabular}{|c|c|c|}
\hline Podstawy przedsiębiorczości & Geografia & Wiedza o społeczeństwie \\
\hline $\begin{array}{l}\text { III. Rynek pracy: mierniki } \\
\text { i wskaźniki, popyt i podaż na } \\
\text { rynku pracy, kariera zawodo- } \\
\text { wa, poszukiwanie pracy, roz- } \\
\text { mowa kwalifikacyjna, formy } \\
\text { zatrudnienia, systemy płac, } \\
\text { prawa i obowiązki pracownika } \\
\text { i pracodawcy, bhp i organiza- } \\
\text { cja pracy, Państwowa Inspek- } \\
\text { cja Pracy, związki zawodowe, } \\
\text { etyka w pracy. } \\
\text { 1) mierniki i wskaźniki rynku } \\
\text { pracy, } \\
\text { 2) wyjaśnia mechanizm popy- } \\
\text { tu i podaży na rynku pracy } \\
\text { 3) szanse i możliwości rozwo- } \\
\text { ju własnej kariery zawodowej } \\
\text { 4) metody poszukiwania pracy } \\
\text { i ich przydatność } \\
\text { 5) analizuje własne kompe- } \\
\text { tencje i możliwości zdobycia } \\
\text { doświadczenia zawodowego } \\
\text { w formie wolontariatu, prak- } \\
\text { tyk lub stażu oraz znalezienia } \\
\text { pracy na rynku } \\
\text { 6) opracowuje dokumenty } \\
\text { aplikacyjne } \\
\text { 7) przygotowuje się do rozmo- } \\
\text { wy kwalifikacyjnej } \\
\text { 8) formy zatrudnienia i rodza- } \\
\text { je umów o pracę } \\
\text { 9) charakteryzuje różne syste- } \\
\text { my płac, rodzaje i formy wy- } \\
\text { nagrodzeń oraz identyfikuje } \\
\text { koszty płacy i oblicza wyna- } \\
\text { grodzenie netto; } \\
\text { 10) analizuje prawa i obowiąz- } \\
\text { ki pracownika (w tym młodo- } \\
\text { cianego) i pracodawcy oraz } \\
\text { omawia specyfikę zatrudnie- } \\
\text { nia osób niepełnosprawnych; } \\
\text { 11) analizuje przepisy Kodeksu } \\
\text { pracy } \\
\text { 12) przedstawia zasady BHP } \\
\text { 13) zna działania PIP, ocenia } \\
\text { zachowania etyczne i nieetycz- } \\
\text { ne pracodawcy i pracowników }\end{array}$ & $\begin{array}{l}\text { XV. 5) zmiany w strukturze } \\
\text { zatrudnienia, przyczyny bez- } \\
\text { robocia i analiza przestrzenne- } \\
\text { go zróżnicowania rynku pracy } \\
\text { w Polsce; } \\
\text { XVI. 3) na podstawie zebra- } \\
\text { nych danych statystycznych } \\
\text { i przeprowadzonych } \\
\text { wywiadów identyfikuje czyn- } \\
\text { niki kształtujące poziom bez- } \\
\text { robocia we własnej } \\
\text { miejscowości i odnosi go do } \\
\text { poziomu bezrobocia we wła- } \\
\text { snym regionie } \\
\text { i w Polsce; } \\
\text { XXI. 6) przyczyny i skutki } \\
\text { bezrobocia w regionach wy- } \\
\text { soko i słabo rozwiniętych ze } \\
\text { szczególnym uwzględnieniem } \\
\text { problemu bezrobocia wśród } \\
\text { ludzi młodych }\end{array}$ & $\begin{array}{l}\text { VII.1) funkcjonowanie syste- } \\
\text { mu obowiązkowych ubezpie- } \\
\text { czeń społecznych (emerytalne, } \\
\text { rentowe, chorobowe i wypad- } \\
\text { kowe; ZUS } \\
\text { VI.7) cele i działania związków } \\
\text { zawodowych } \\
\text { IX. 9) polityka państwa na } \\
\text { rynku pracy, świadczenia so- } \\
\text { cjalne dla bezrobotnych; } \\
\text { XI. 14) wzory umów zlecenia } \\
\text { i umów o dzieło } \\
\text { 15) umowa o pracę } \\
\text { 16) formy zatrudnienia } \\
\text { XVI. 1) w jaki sposób można } \\
\text { podnosić lub zmieniać swoje } \\
\text { kwalifikacje zawodowe; ucze- } \\
\text { nie się przez całe życie jako } \\
\text { warunek sukcesu w karierze } \\
\text { zawodowej }\end{array}$ \\
\hline
\end{tabular}

Źródło: opracowanie własne 
jak np. poznawanie skomplikowanych relacji i zjawisk, analiza związków przyczynowo-skutkowych i poszukiwanie realistycznych i aplikacyjnych rozwiązań problemu.

Istnieje kilka możliwości praktycznej realizacji modelu interdyscyplinarnego w szkole w zakresie korelacji podstaw przedsiębiorczości, geografii i wiedzy o społeczeństwie. Najczęściej polecaną w literaturze dydaktycznej metodą scalania treści i aktywizacji uczniów jest metoda projektu (Chałas, 2000; Grondas, 1999; Grządziel i in., 2011; Kruszewski, 2007; Mikina, Zając, 2001). Polega ona na realizacji przez uczniów określonego przedsięwzięcia edukacyjnego według wyznaczonych zasad (form realizacji pracy, terminów, składu osobowego zespołu itp.). Ze względu na przedmiot pracy projekty możemy podzielić na:

- badawcze - polegają one na samodzielnym gromadzeniu przez uczniów informacji o pewnym wycinku rzeczywistości i ich interpretacji, np. samodzielne badania metodą sondażu diagnostycznego przeprowadzonego we własnej miejscowości i analiza ich wyników,

- społeczno-obywatelskie - opierają się one na planowaniu i realizacji przez uczniów działań społecznych, a nawet drobnych przedsięwzięć ekonomicznych w środowisku lokalnym,

- medialno-artystyczne - polegają one na tworzeniu tematycznych utworów: artykułów, wierszy, filmów, audycji, sztuk teatralnych, wystaw itp.

Spośród wskazanych szczególnie wartościowa $\mathrm{z}$ dydaktycznego punktu widzenia jest korelacja omawianych przedmiotów przez projekty badawcze i społeczno-obywatelskie.

Inną formą realizacji modelu multidyscyplinarnego jest zaprojektowanie i przeprowadzenie wspólnie z uczniami ścieżki dydaktycznej lub wycieczki szkolnej. Wyjście w teren nie zawsze musi być przecież związane z dokonywaniem obserwacji przyrodniczych. Warto zaplanować społeczno-ekonomiczną trasę po najbliższej okolicy ucznia, taką, by znalazły się na niej obiekty potencjalnie znaczące w jego przyszłym dorosłym społecznym i zawodowym życiu: urząd gminy, urząd pracy, największy pracodawca w okolicy, drobny przedsiębiorca, ważna fundacja społeczna czy dom pomocy społecznej.

Ostatnimi godnymi polecenia formami realizacji modelu interdyscyplinarnego są realizowane wspólnie przez nauczycieli trzech przedmiotów zajęcia pozalekcyjne w szkole (np. ekonomiczne kółko zainteresowań) oraz imprezy szkolne (np. tematyczne dni otwarte).

\section{Podsumowanie}

Wprowadzana obecnie do polskich szkół reforma oświaty z powodu znaczących zmian organizacyjnych i merytorycznych powoduje wśród nauczycieli pewien niepokój. Z drugiej jednak strony zmiana daje szansę na usprawnienie procesu kształcenia, w tym w zakresie podstaw przedsiębiorczości. Postawiona przez autorkę na początku pracy hipoteza, że pomimo zmian programowych podstawy przedsiębiorczości w szkole ponadpodstawowej nadal będą miały niższą pozycję od większości przedmiotów szkolnych, potwierdziła się częściowo.

Analiza pozycji przedmiotu podstawy przedsiębiorczości w zreformowanej szkole średniej na tle innych przedmiotów szkolnych była dokonywana przez autorkę $\mathrm{z}$ dwóch punktów widzenia: formalnego i koncepcyjnego. Wyniki analizy z punktu widzenia formalnego wykazały, że według Ramowego planu nauczania przedmiot nie zyska na 
znaczeniu, pozostając przedmiotem o małej liczbie godzin, „niematuralnym” i niewystępującym w zakresie rozszerzonym. Rozpatrując jednak przedmiot z punktu widzenia koncepcji kształcenia jako przygotowania ucznia do dorosłego życia, w tym życia ekonomicznego, zakres treści kształcenia podstaw przedsiębiorczości sytuuje go na znaczącej pozycji.

Analiza źródeł naukowych, założeń dydaktycznych i treści kształcenia zawartych w nowej podstawie programowej do szkoły średniej wykazała, że przygotowanie ucznia do ekonomicznej sfery życia leży w gestii nauczycieli trzech przedmiotów: podstaw przedsiębiorczości, geografii i wiedzy o społeczeństwie.

Treści nauczania wskazanych trzech przedmiotów są koherentne i umożliwiają przeprowadzenie scalania. Scalanie owo w procesie kształcenia może przyjmować formy: korelacji przedmiotowej, korelacji międzyprzedmiotowej lub integracji międzyprzedmiotowej, przeprowadzonej wg monodyscyplinarnego, interdyscyplinarnego lub multidyscyplinarnego modelu kształcenia. Modelem kształcenia najbardziej sprzyjającym budowaniu u ucznia holistycznej wiedzy ekonomicznej jest model multidyscyplinarny. Wśród form realizacji tego modelu najbardziej efektywną i efektowną jest metoda projektu. Najbardziej polecanymi przez autorkę z dydaktycznego punktu widzenia odmianami tej metody umożliwiającymi scalane treści podstaw przedsiębiorczości, wiedzy o społeczeństwie i geografii, są projekty badawcze i społeczno-obywatelskie.

Literatura

References

Chałas, K. (2000). Metoda projektu i jej egzemplifikacja w praktyce. Warszawa.

Grondas, M. (1999). Projekt jako narzędzie integracji międzyprzedmiotowej. W: Program „Nowa Szkoła". Materiały szkoleniowe dla rad pedagogicznych. Integracja międzyprzedmiotowa. Warszawa

Grządziel, H., Kos-Górczyńska, I., Stańczyk, A., Szczur, H. (2011). Przewodnik dla nauczycieli w zakresie prowadzenia korelacji przedmiotów ogólnych i zawodowych. Warszawa.

Kruszewski, K. (red). (2007). Sztuka nauczania. Czynności nauczyciela. Warszawa: Wydawnictwo Naukowe PWN.

Mikina, A., Zając, B. (2001). Jak wdrażać metodę projektu?, Kraków: Wydawnictwo Impuls.

Rachwał, T., (2005). Kształtowanie postaw uczniów na lekcjach podstaw przedsiębiorczości. Przedsiębiorczość - Edukacja, 1, 137-143.

Okoń, W., (2003). Wprowadzenie do dydaktyki ogólnej. Warszawa: Wydawnictwo Akademickie Żak.

Ramowy plan nauczania dla liceum ogólnokształcacego, w tym liceum ogólnoksztatcacego specjalnego dla uczniów w normie intelektualnej: niepelnosprawnych, niedostosowanych społecznie oraz zagrożonych niedostosowaniem społecznym. Załącznik do: Rozporządzenie Ministra Edukacji Narodowej $z$ dnia 28 marca 2017 r. w sprawie ramowych planów nauczania dla publicznych szkót, Dz.U. 2017, poz. 703.

Rozporządzenie Ministra Edukacji Narodowej z dnia 14 lutego 2017 r.w sprawie podstawy programowej wychowania przedszkolnego oraz podstawy programowej kształcenia ogólnego dla szkoły podstawowej, w tym dla uczniów z niepełnosprawnością intelektualną w stopniu umiarkowanym lub znacznym, kształcenia ogólnego dla branżowej szkoły I stopnia, kształcenia ogólnego dla szkoły specjalnej przysposabiającej do pracy oraz kształcenia ogólnego dla szkoły policealnej, Dz.U. 2017, poz. 356.

Stepulak, M. (2017). Holistyczne podejście do wychowania moralnego i społecznego we współczesnym systemie oświatowym w Polsce. Studia i Prace Pedagogiczne, 4, 13-26. 
Szyszko-Bohusz, A. (2002). Pedagogika holistyczna w okresie przemian współczesnej humanistyki. W: J. Gnitecki (red.). Teorie pedagogiczne wobec zmian w humanistyce i w otaczającym świecie. Olsztyn-Poznań.

Świętek, A. (2012). Oczekiwania a realia wejścia ludzi młodych na rynek pracy jako wyzwanie dla edukacji z przedsiębiorczości. Przedsiębiorczość - Edukacja, 8, 137-154.

Świętek, A. (2016). Edukacja jako element poziomu życia romskiej mniejszości etnicznej w województwie małopolskim. Cz. I: Poziom życia Romów w województwie małopolskim. Kraków: Wydawnictwo Naukowe Uniwersytetu Pedagogicznego.

Wach, K. (2013). Edukacja na rzecz przedsiębiorczości wobec współczesnych wyzwań cywilizacyjno-gospodarczych. Przedsiębiorczość - Edukacja, 9, 246-257.

Zawiślak, A. (2000). Czym jest właściwie nauczanie blokowe? W: K. Waligórski (red.), Reforma edukacji - realia, szanse, zagrożenia. Bydgoszcz-Wągrowiec: Akademia Bydgoska im. Kazimierza Wielkiego, 87-94.

Zioło, I. (1999). Wybrane atrybuty wartości edukacyjnej wyższej szkoły niepaństwowej. Zeszyty Naukowe Wyższej Szkoły Informatyki i Zarządzania w Rzeszowie, 3, 127-146.

Agnieszka Świętek, dr, nauk o ziemi w zakresie geografii, absolwentka studiów z zakresu geografii Uniwersytetu Pedagogicznego im. Komisji Edukacji Narodowej w Krakowie w specjalności przedsiębiorczość i gospodarka przestrzenna. Adiunkt w Instytucie Geografii Uniwersytetu Pedagogicznego w Krakowie. Jej zainteresowania badawcze skupiają się wokół dwóch tematów: problematyki edukacji z zakresu geografii i przedsiębiorczości, a w szczególności procesu zakładania własnej działalności gospodarczej, wchodzenia młodych ludzi na rynek pracy, oraz poziomu życia Romów w Polsce.

Agnieszka Świętek, PhD in Geography, graduated from the Pedagogical University of Cracow with an MA degree in Geography, with a specialisation in Entrepreneurship and spatial planning. Associate professor at the Pedagogical University of Cracow, Institute of Geography. Her research interests focus on different research themes: education in the field of geography and entrepreneurship, in particular the process of starting up own business, young people entering into the labor market, and the quality of life of Roma in Poland.

ORCID: 0000-0002-5049-6476

\section{Adres/Address:}

Uniwersytet Pedagogiczny im. Komisji Edukacji Narodowej w Krakowie

Instytut Geografii

Zakład Dydaktyki Geografii

ul. Podchorążych 2

30-084 Kraków, Polska

e-mail: aswietek@up.krakow.pl 